\title{
PERCEPTION OF DIGITAL GAMES AS EDUCATIONAL MEDIA BY LOWER SECONDARY SCHOOL PUPILS
}

\author{
Karel PICKA*, Masarykova Univerzita, Česká republika ${ }^{1}$ \\ Karolína PEŠKOVÁ, Masarykova Univerzita, Česká republika
}

Přijato: 7. 1. 2018/ Akceptováno: 20. 3.2018

Typ článku: Výzkumná studie

DOI: $10.5507 /$ jtie.2018.002

Abstract: The aim of the research survey presented in this study was to find out how pupils of lower secondary schools perceive digital games as an educational medium. The partial objective was to find out whether pupils have encountered digital games within their education and how they are motivated to play digital games. The study focusing on pupils is another step for understanding the possibilities of digital games in the field of education. The study utilized a questionnaire, which was filled in by 603 lower secondary school pupils, in order to gain the data. The results showed that pupils perceived games primarily as an element that encouraged their imagination and they wanted to use the digital games as a medium in their education.

Key words: perception of digital games, motivation, game-based learning, questionnaire survey, pupils.

\section{VNÍMÁNÍ DIGITÁLNÍCH HER JAKO VZDĚLÁVACÍHO MÉDIA ŽÁKY ZÁKLADNÍCH ŠKOL}

Abstrakt: Cílem výzkumného šetřeni prezentovaného v této studii bylo zjistit, jak žáci základních škol vnímaji digitální hry jako vzdělávaci médium. Dílčím cílem bylo zjistit, zda se žáci s digitálními hrami setkali v rámci vzděláváni a jak jsou $k$ hrani digitálních her motivováni. Studie je dalším krokem v pochopení možností digitálních her na poli vzdělávání. Využila pro ziskání potřebných dat dotazník, který byl vyplněn 603 žáky 2. stupně ZŠ. Z výsledků např. vyplynulo, že žáci hry vnímali predevšim coby element, jenž podněcuje jejich představivost, a uvedli, že by se s ním jako s médiem chtěli ve svém vzděláváni dále setkávat.

Klíčová slova: vnímání digitálních her, motivace, game-based learning, dotazníkové šetření, žáci.

\footnotetext{
1 Studie vznikla za podpory projektu Výzkum edukačních procesů, podmínek a prostředků (MUNI/A/1244/2016).

* Autor pro korespondenci: $318732 @$ mail.muni.cz
} 


\section{1 Úvod}

Digitální hry jsou bezpochyby jedním z hlavních médiii ${ }^{2}$, které dnešní mladí lidé konzumují. At' již se jedná o hry na počítačích, dedikovaných herních zařízeních (konzolích) nebo mobilních telefonech, znalost tohoto kulturního fenoménu je pro žáky základních škol prakticky automatická. V rámci České republiky máme v tomto směru data již poněkud starší (ISFE, 2012), nicméně výzkumy americké NPD group, popřípadě Entertainment Software Association naznačují, že ve věku 2 až 17 let hraje více než $90 \%$ dětí. Ostatně v posledních letech se na toto téma ani výzkumy, respektive velké studie trhu nijak zvlášt' nezaměřují, a to hlavně proto, že není nutné zkoumat, jestli děti a mladí lidé hrají, ale spíše jak, na čem a jak dlouho hrají. Hra jako médium se integrovala do naší kultury a žádný trend nenasvědčuje tomu, že by se to mělo v budoucnu měnit.

Velké studie herního průmyslu se dotazují hráčů na spoustu faktorů, které ovlivňují jejich herní zážitek a preference. Podobný přístup je potřeba ustanovit i v pedagogické vědě, protože kromě her běžně využíváme všechna dostupná média. Her určených pro vzdělávání je nicméně v kontextu České republiky jen velice málo a často nemají konkrétní návaznost na kurikulum, jako je tomu v př́padě učebnic nebo edukačních videomateriálů. Neznamená to ovšem, že hry nejsou v edukační realitě využívány nebo se v tomto směru nic nemění. Učitelé se snaží využívat i hry, jež pro vzdělávání původně určené nebyly (např. Adams, 1998; Tannahill et al., 2012; Short, 2012), i ryze edukační hry (Philpot, 2005; Charsky, 2010; Deveau et al., 2014; v českém prostředí pak také Brom, Šisler, \& Slavík, 2010; Picka, 2017). Nicméně zahraniční učitelé a pedagogičtí výzkumníci se problematice věnují mnohem více (Watson \& Yang, 2016; Takeuchi \& Vaala, 2014; Proctor \& Marks, 2013), což samozřejmě souvisí i s jiným socioekonomickým vývojem a př́istupem k ICT. Zatímco v USA první vzdělávací počítačové hry vycházejí již v 70. a 80. letech 20. století (např. Oregon Trail), u nás se začaly objevovat až v polovině 90 . let. Za zmínku stojí např́iklad herní tituly pro výuku angličtiny od firmy LANGMaster. V téže době také vzniká nemalá řada vzdělávacích programů (třeba i od firmy LANGMaster, nebo hojně rozšířené produkty od firmy Terasoft), které sice obsahují některé herní prvky, nicméně o svébytné herní tituly se nejedná už proto, že herní prvek je velice minimalistický a většinou se vzdělávacím elementem nesouvisí. Slouží spíše k zatraktivnění transmise vzdělávacího obsahu, podobně jako například doplňkové (s učivem nesouvisející) ilustrace v běžných učebnicích. Pro tento prristup se v literatuře zabývající se digitálními vzdělávacími hrami zažil termín „brokolice v čokoládě“ (např. Hopkins \& Roberts, 2015), který vystihuje onu odtrženost vzdělávacího obsahu od herní složky. Oproti tomu digitální hra určená (nebo i jen využívaná) pro vzdělávání, není nesourodým kompilátem, jakousi brokolicí v čokoládě, ale svými principy, mechanikami i prostředím se týká zamýšleného vzdělávacího obsahu, zatímco si udržuje hratelnost. Ve stejné době se počítač stává i v České republice více středoproudovou záležitostí a vzdělávací software (nikoliv však nutně hry) bývá často obsažen v balení k domácím počítačům. Objevují se první pobídky pro IT do škol a vzdělávací software se pomalu dostává i sem. Kvůli velice rozdílnému vývoji se proto nabízí prozkoumat názory žáků na tuto problematiku a jejich pohled na hry jako na vzdělávací médium. Ostatně dobrá škola by měla být schopna se adaptovat na výrazné technologické a společenské změny, aby se nestávala anachronickou.

\footnotetext{
${ }^{2}$ Digitální hry chápeme jako prostředek komunikace, tedy jako prostředníka pro sdělení obsahu, který je do něj vložen, podobně jako je toho např. u filmu.
} 


\section{Digitální hry v primárním a nižším sekundárním vzdělávání}

Vzdělávací obsah lze zprostředkovat pomocí široké škály médií. Tradičně můžeme říci, že nejzásadnějším vzdělávacím médiem, respektive prostředkem interakce mezi žákem a učitelem, je didaktický verbální a nonverbální text, v současnosti často doplňovaný o různé typy audia, videa nebo multimédií (Radu, 2014; Kruesmann, 2014). Pro potřeby této studie se zaměřujeme na digitální hru jako na jeden $\mathrm{z}$ typů vzdělávacích médií - prostředků interakce mezi žákem a probíranou látkou (Squire, 2008). Oproti ostatním multimediálním prostředkům je její výhodou právě interaktivní obsah (viz Squire, 2008; Gee, 2004).

Jak již bylo řečeno $\mathrm{v}$ úvodu, $\mathrm{v}$ západním světe bylo možné setkat se s digitálními hrami ve vzdělávání poměrně často již od 80 . let a už tehdy vznikaly i první studie, které zjišt'ovaly dopady použití digitální hry coby vzdělávacího média na vzdělávání. Pokud se podíváme na hry ve vzdělávání $\mathrm{z}$ hlediska motivačního rámce, jejž jako první představili Malone a Lepper (1987), zjistíme, že autoři definovali několik motivačních faktorů prítomných v hrách. Ty také rozdělili na osobní (výzva, zvědavost, fantazie, kontrola nad prostředím) a několik mezilidských (kooperace, soutěž, uznání). Ostatně některé tyto motivační faktory (nap̌r. soutěž nebo kontrola nad prostředím) souvisejí i s dalším zmiňovaným a rozvíjeným aspektem digitálních her. Tím je změna strategie ve vzdělávání od „učení se nasloucháním“ k „učení se konáním“ (Garris et al., 2002). Takto nastavený výukový rámec pak klade důraz na design imerzních zážitků a řešení problémů spojených s výukovým cílem (Squire, 2008). Tento př́istup je ve výzkumech poměrně často ověřován jako spolehlivý nástroj, nicméně je primárně srovnáván jen s tradiční (frontální) výukou. Např́klad studie autorů Shin a kol. (2012) zaměřená na výuku matematiky pomocí digitálních her konstatuje, že zlepšení prostřednictvím digitální hry se neprojevuje v závislosti na tom, jakou výkonnost $\mathrm{v}$ předmětu (zjištovanou pomocí testů) student měl. Studie přitom zkoumala efekt her na podporu matematiky u poměrně mladých žáků - ve věku 7 a 8 let. U ještě mladších dětí, tentokrát již v předškolním vzdělávání, byl zaveden soubor výukových her, jenž měl podporovat rozvoj jazykových schopností dětí (Segers \& Verhoeven, 2005). Byl zpozorován větší rozvoj schopností u dětí, které po celý rok spolupracovaly s výukovými hrami než u kontrolní skupiny, jež byla vyučována tradičně. Autoři také uvádějí, že hlavními pozitivy výukových her byly kromě zábavnosti především možnost nekonečné repetice problému, okamžitá zpětná vazba a také fakt, že se děti necítily být souzeny za svoje neúspěchy, a to jak učiteli, tak vrstevníky.

Často uváděným prrínosem digitální hry jako metody je vnitřní motivace žáků. Zatímco motivaci vnější mohou do vzdělávání přidat další aktéři vzdělávacího procesu (učitelé, rodina), tu vnitřní je potřeba $\mathrm{v}$ žákovi vzbudit bez ohledu na možnou odměnu. Ostatně vnitřní motivace je právě provádění aktivity (v tomto př́ípadě výukové aktivity) o svobodné vůli a bez očekávání externí odměny (Deci, 1971). Historický problém edutainmentových ${ }^{3}$ her však spočíval v tom, že herní prvek byl pouze přidanou hodnotou za řešený edukativní obsah (Habgood \& Ainsworth, 2011). Jednalo se tedy stále pouze o „brokolici v čokoládē“ (Bruckman, 1999) a ne o vnitřní motivaci využívat vzdělávací produkt jako celek. Studie, která zkoumala využití her ve studiu matematiky na základní škole (Habgood \& Ainsworth, 2011), zde navíc dochází k závěru, že jakkoliv je vnitřní motivace pozitivní

\footnotetext{
${ }^{3}$ Edutainment (tedy education \& entertainment) byl směr, jímž se někteří vývojáři začali ubírat již v 80. letech. Kvalita těchto projektů však byla velice diskutabilní, jelikož herní složka vůbec nesouvisela se složkou vzdělávací. Př́íkladem může být hra Adventures in Math (IBM, 1983).
} 
záležitostí, je nutné, aby byl kladen velký důraz na tvorbu zábavných a funkčních základních mechanik hry a teprve poté byla řešena jak konkrétní herní fantazie, tak specifický vzdělávací obsah. K podobným závěrům, co se vnitřní motivace ale i konstrukce a kvality hry týče, dochází i další studie (Wang et al., 2010) provedená na 124 žácích rozdělených do dvou experimentálních a dvou kontrolních skupin. Kromě pozitivních závěrů vzhledem $\mathrm{k}$ vnitřní motivaci žáků a lepších dosažených výsledků autoři též vyzdvihují navázání lepšího, prúatelštějšího vztahu s učitelem, se kterým sdílejí herní zkušenost. Upozorňují však na možnou „,přemotivovanost“ (over motivation) žáků, jež může vést ke zbytečným chybám.

Dalšími otázkami motivace se zabývali Vos, van der Meijden a Denessen (2011), a to v experimentu, kde žáci byli rozděleni do dvou skupin: jedna skupina hrála existující hru na podporu paměti a logického myšlení, zatímco druhá skupina takovou hru i tvořila. $\mathrm{V}$ tomto př́padě autoři uvádějí, že žáci, kteří mohli hru i sami tvořit, byli mnohem motivovanější $\mathrm{k}$ další činnosti. Rovněž však připouštějí, že použité hry byly poměrně málo komplexní. K podobným závěrům, tedy že tvorba hry je pro žáky zajímavější jak z hlediska edukačního dopadu, tak z hlediska motivace, docházejí i další studie. Výzkum provedený na skotských školách (Robertson \& Howells, 2008) použil již poměrně komplexnějšího prostředí - vývojový nástroj (toolset4) pro tvorbu obsahu pro RPG hru Neverwinter Nights (2002). Byl proveden na skupině žáků mezi 10 a 12 lety a trval šest týdnů. Při kvalitativním sběru dat mezi participujícími žáky se zjistilo, že velice motivující byl pro žáky právě element tvorby hry, nejen pouhého hraní. Žáci shledávali výzvy, jež na ně vývojové prostředí kladlo, jako vysoce zábavné i v momentech, kdy jim určitý záměr nevycházel a museli si pročíst podpưrné materiály nebo jít konzultovat s vyučujícím. Dle Clancyho (2004) mají děti problémy s pochopením programového prostředí, a pokud nemají osvojeny alespoň nějaké základní programátorské dovednosti, hru vytvářejí jen s velkými obtížemi. Novější výzkumy ovšem ukazují (např. Denner et al., 2012), že když je použito adekvátní vývojové prostředí a poskytnuta citlivá podpora pedagoga, je možné, aby většina žáků byla schopna vytvořit základní typy her, a tím se naučila řešit problémy tohoto druhu.

Uvedený přehled dosavadních výzkumů na téma digitálních her ve výuce naznačuje, že převažují studie zabývající se zjištováním dopadů digitálních her na výkonnost a motivaci žáků $\mathrm{k}$ učení. Studií, které by řešily samotné vnímání digitálních her jako vzdělávacího média, je nedostatek. V tomto ohledu shledáváme mezeru i ve výzkumu v českém prostředí. Domníváme se však, že abychom mohli dále zjišt’ovat efekt nasazení digitálních her do výuky, je třeba nejdř́ve prozkoumat, zda toto médium má vůbec vzdělávací potenciál. $\mathrm{V}$ naší studii přistupujeme $\mathrm{k}$ tomuto problému $\mathrm{z}$ perspektivy žáků coby hlavního „konzumenta“ vzdělávacích her. V centru naší pozornosti je tak vnímání digitálních her žáky jako možného vzdělávacího média.

\section{Metodologie}

\subsection{Cíle a výzkumné otázky}

Cílem výzkumného šetření bylo zjistit, jak žáci základních škol vnímají digitální hry jako vzdělávací médium. Dílčím cílem bylo zjistit, zda se žáci s digitálními hrami setkali

\footnotetext{
${ }^{4}$ Toolset je sada přednastavených vývojářských nástrojů obsažených v nějakém uceleném balíčku, který umožňuje tvorbu částí aplikace (Collins English Dictionary, 2012).
} 
během vzdělávání (ve škole, doma, v kroužcích) a jak jsou žáci k hraní digitálních her motivovaní. Výzkumné cíle jsme formulovali s ohledem na výsledky obdobných výzkumů (viz kapitola 2), a to jak v oblasti vnímání digitálních her, tak v oblasti motivace $\mathrm{k}$ hraní her (např. Habgood \& Ainsworth, 2011; Wang et al., 2010; Hainey et al., 2013). Výzkumná studie také navazuje na předešlý výzkum (Picka, 2017), který mapoval vnímání digitálních her učiteli základních škol.

Uvedené cíle jsme specifikovali prostřednictvím následujících výzkumných otázek:

1. Jaké hry, jak a jak často žáci hrají ve volném čase?

2. S jakými digitálními hrami se žáci setkávají v rámci vzdělávání? Jak využívají žáci hry v domácím učení?

3. Co žáky motivuje $\mathrm{k}$ hraní her?

4. Jaké faktory mají na vnímání učení se s digitálními hrami vliv?

5. Jaké faktory mají na motivaci k hraní digitálních her vliv?

\subsection{Výzkumný nástroj}

Pro dosažení výzkumných cílů bylo realizováno výzkumné šetření využívající dotazníku coby nástroje ke sběru dat. Př́i operacionalizaci sledovaných konstruktů (vnímání digitálních her, motivace $\mathrm{k}$ hraní digitálních her) i samotné tvorbě nástroje (jeho škál a položek) jsme vycházeli ze zahraničních studií a jejich již aplikovaných dotazníků a částečně i z vlastního předchozího šetření (Picka, 2017). Adaptace se týkala především konstruktu motivace, přičemž položky byly přejaty ze studie Haineyho et al. (2013) stavěící na rámci vnitřní motivace definované Malonem a Lepperem (1987). Osobní motivy5 operacionalizované zmíněnými autory jsme přejali především z důvodu jejich přiléhavého napojení na problematiku učení se s hrami. Studie Haineyho et al. sice pracovala původně s jiným vzorkem (studenti terciálního vzdělávání), nicméně položky byly v naší studii přizpůsobeny tak, aby jim cílová skupina respondentů (žáci 2. stupně ZŠS) co možná nejlépe rozuměla a aby vyhovovaly kontextu českého vzdělávání.

Po pilotáži6 (na souboru 72 žáků) výsledný dotazník obsahoval 42 položek, z toho 18 hodnocených pomocí pětibodové Likertovy stupnice (souhlasím - spíše souhlasím nevím - spíše nesouhlasím - nesouhlasím), 23 položek polouzavřených a uzavřených a 1 položku otevřenou, určenou k vlastnímu vyjádření. Jednotlivé položky dotazníku pak spadaly do předem nadefinovaných tematických oblastí (škál):

(1) Demografické a kontextové otázky (14 položek)

V této oblasti jsme se ptali na respondentův věk, obec, navštěvovaný ročník ZŠ a školní př̀edmět, jejž má respondent v oblibě. Nacházely se zde také položky, které zjištovaly respondentovo zaujetí ICT. V minulosti byly digitální hry často dávány do kontextu (primárně laickou veřejností, ale nejenom tou) s obecným zájmem o výpočetní techniku, nicméně pro kontext výzkumu jsme se rozhodli tento fakt ověřit. Cílem tedy nebylo zjistit respondentovy znalosti a schopnosti na ICT poli, ale právě jeho zájem. Byl

\footnotetext{
${ }^{5}$ Jedná se o následující motivy: učení se s hrou jako výzva, podněcování zvídavosti, kontrola nad učebním prostředím a rozvoj fantasie.

${ }^{6}$ Z pilotáže vyplynula zpřesnění a reformulace některých otázek, respektive i vyřazení několika otázek. Pilotáž rovněž umožnila lépe formulovat úvodní text dotazníku, který seznamoval respondenty s jeho obsahem.
} 
zjištován pomocí čtyř dichotomických otázek, jež se týkaly různých zkušeností a zájmů ze světa ICT (hardware, programování apod.).

V této části dotazníku jsme se také ptali (pomocí pěti položek -2 uzavřených, 2 polouzavřených a 1 otevřené) na to, jaké hry respondenti hrají, jak častá je frekvence jejich hraní a jaké žánry jsou mezi respondenty oblíbené.

(2) Hry a škola (5 položek)

Tato oblast dotazníku obsahovala otázky, které se týkaly zkušeností respondentů s digitálními hrami ve školním prostředí. Především však obsahovala důležitou filtrační otázku, zda se respondent vůbec někdy s digitálními hrami ve školní výuce setkal. Dle odpovědi na tuto položku pak dostali respondenti relevantní položky, jež se týkali jejich prímé zkušenosti (v jakém předmětu, konkrétní hra a také jaké mělo použití her vliv na jejich př́istup $\mathrm{k}$ výuce, tedy zda pro ně byla výuka zábavnější). Respondenti, kteří se $\mathrm{s}$ hrou nesetkali, tyto položky ,přeskočili“. Dále pak byly v této oblasti použity položky, jež opět zkoumaly, jaké hry se respondentům samým jeví jako vhodné pro jejich školní výuku. Tato část dotazníku obsahovala celkem 5 položek - 1 dichotomickou, 2 otevřené, 1 polouzavřenou a 1 položku hodnocenou na pětibodové Likertově stupnici.

(3) Používání digitálních her (3 položky)

Cílem těchto položek bylo zjistit, jestli se žáci setkávají s digitálními hrami určenými pro výuku i mimo školní prostředí. Oblast tak pomocí 2 dichotomických a 1 polouzavřené položky zkoumala, kde jinde se respondenti setkali (a zda vůbec) s digitální hrou pro výuku, jestli jim ji někdy doporučili nebo dali rodiče, popř́ípadě jestli si oni sami někdy aktivně hledali digitální hry, které souvisely s tématem vyučovaným ve škole.

(4) Vnímání učení se s digitálními hrami (6 položek)

Jednalo se o poměrně obsáhlou oblast, jež se zaměřovala na respondentovo vnímání zapojení her do svého procesu učení. Např́klad jsme zjišt'ovali, jestli jsou digitální hry vnímané jako prvek, který respondentovi spíše v učení pomáhá, jestli mu učivo lépe přibližuje nebo zda by se chtěl pomocí digitálních her více vzdělávat doma, či ve škole. Všechny položky byly hodnoceny na pětibodové Likertově škále.

(5) Motivace k hraní digitálních her (6 položek)

Oblast využila 5 položek (všechny dle pětibodové Likertovy stupnice), které řešily právě motivaci u digitálních her - tedy jestli respondenta motivuje kompetitivnost hry, její náročnost, únik do fantazie a další faktory (viz Hainey et al., 2013).

(6) Klady a zápory konkrétní vzdělávací hry (6 položek)

Otázky v této oblasti měly za cíl zjistit, zdali se respondent dokáže zaměřit na jednu hru (kterou si sám určil v otevřené otázce), s níž měl zkušenost, a definovat, jak tento titul ovlivnil jeho vzdělávání. Tedy jestli mu tato konkrétní digitální hra dokázala látku zprostředkovat lépe či zábavněji a namotivovala ho se něco více o problematice dozvědět. Konkrétní herní titul pak slouží spíše jako kontextová informace, nejdůležitější v této oblasti je dozvědět se, zda si respondenti sami uvědomují jejich vlastní práci s digitální vzdělávací hrou. Do oblasti spadalo 6 položek, z čehož 1 byla filtrovací - předurčila, jestli respondent dostane baterii otázek týkající se konkrétní hry. Dále se použilo 5 otázek, z nichž 1 byla otevřená a 4 byly hodnoceny na pětibodové Likertově stupnici.

Dotazník obsahoval 3 rozřazovací položky, dle kterých respondent vybral př́slušné navazující položky: první rozrazovací položka, Hraješ alespoň někdy na počitači, konzoli, na internetu (třeba jen v prohližeči) nebo na mobilu nějaké hry?, jež byla kladena po kontextových a demografických otázkách, pomohla určit, zda respondent má alespoň nějaké zkušenosti s digitálními hrami. Pokud zkušenosti neměl vůbec žádné (tedy nikdy 
a na žádné platformě digitální hry nehrál), v dotazníku přešel $\mathrm{k}$ ukončení, protože by pro něj další otázky neměly smysl. Takto byl však dotazník ukončen jen ve velmi malé skupině respondentů $(7,46 \%)$. Další rožrazovací položka dotazníku zněla takto: Setkal/a jsi se někdy ve škole v rámci výuky s digitálními hrami? Respondenty rozřadila na ty, kteří se ve výuce s digitálními hrami setkali a kteří ne. Ti, již se s nimi setkali, pokračovali několika položkami, které souvisely s jejich zažitou zkušeností s digitálními hrami ve výuce. Poslední rožrazovací položkou byla otázka cílící na konkrétní hru, s níž se respondenti setkali: Hrál/a jsi někdy digitální hru (jakoukoliv), u které jsi mělla pocit, že ses naučil/a něco do školy? Ti z respondentů, již odpověděli kladně, dostali závěrečnou baterii pěti otázek, které zjišt'ovaly respondentův názor na tuto konkrétní hru.

\section{Analýza dat}

Po ukončení dotazníkového šetření byla data překódována do číselné podoby a následně analyzována pomocí deskriptivní (relativní četnosti, aritmetický průměr) a induktivní statistiky pro neparametrická data (Mann-Whitney test, Kruskal-Wallis $\mathrm{H}$ test). Testy normality (jak Kolmogorov-Smirnov, tak i Shapiro-Wilk test) totiž poukázaly na nenormální rozdělení $(\mathrm{p}<0,05)$. Data byla analyzována $\mathrm{v}$ programu Excel a IBM SPSS 24.

Při zjištování faktorů, které mohou mít na vnímání učení se s digitálními hrami a motivaci $\mathrm{k}$ hraní digitálních her vliv, jsme se $\mathrm{v}$ této studii zaměřili na ty, $\mathrm{u}$ nichž lze tento vliv předpokládat - žákův vztah $\mathrm{k} \mathrm{ICT}{ }^{7}$ a ročník navštěvovaný žákem.

Spolehlivost výzkumného nástroje byla ověřována pomocí výpočtu hodnoty Cronbachova alfa. Počítala se reliabilita u otázek Likertova typu. Celková hodnota reliability činila $\alpha=0,73$. U konstruktu vnímání digitálních her byla získána hodnota $\alpha=$ $0,68, \mathrm{u}$ motivace $\mathrm{k}$ hraní her $\alpha=0,31$. Nízké hodnoty $\alpha$ zapříčila především položka, $K d y z ̌$ dohraji hru, mám dobrý pocit, kterou jsme se však z důvodu věcné důležitosti rozhodli pro další analýzy dat ponechat. Pokud by byla odstraněna, $\alpha$ u motivace by činila 0,64 . Hraniční hodnota pro Cronbachovo čítala 0,7 (Cronbach, 1951). Hodnoty mezi 0,5 a 0,7 je pak možné brát jako akceptovatelné, pokud se jedná o předvýzkum, nebo pokud je šetření provedeno v zemi poprvé a položky jsou adaptované ze zahraničí (Bendermacher, 2010; Cortina, 1993), což je i př́pad tohoto výzkumu, byt' byla celková reliabilita nad hraniční hodnotou.

\subsection{Respondenti}

Elektronický dotazník byl distribuován oslovenými učiteli na náhodně vybraných 45 základních školách. Sběr dat probíhal online pomocí služby vyplnto.cz v období květen-červen 2017. Účastníci tohoto výzkumného šetření byli vybráni ze základního souboru žáků 2. stupně základních škol v České republice. Do konečného výběrového souboru se dostalo 603 respondentů, kteří dotazník kompletně vyplnili. Vzhledem $\mathrm{k}$ anonymitě dotazníku a nemožnosti zjistit, kolik žáků, na které škole dotazník vyplnilo, nelze zjistit přesnou návratnost dotazníku, nicméně ji odhadujeme na cca $45 \%$.

Nejpočetněji zastoupeni byli respondenti ve věku 12 let (30,85\%), 14 let (22,39\%) a 13 let $(19,73 \%)$. Nejčastěji navštěvovali 6 . (37,98 \%) a 7. (22,55 \%) tř́́du 2. stupně ZŠ. Jako

\footnotetext{
${ }^{7}$ Sílu vztahu k ICT jsme rozlišovali podle dosaženého počtu bodů ve 4 otázkách vztahujících se $\mathrm{k}$ ICT (viz kapitola 4.1) - dle odpovědí ano/ne byl proveden součet bodů ze všech otázek. Podle toho jsme určili: velmi silný, silný, středně silný, slabý, velmi slabý vztah k ICT.
} 
svoje nejoblíbenější školní předměty respondenti uváděli tělocvik $(47,6 \%)$, informatiku $(25,7 \%)$, matematiku $(18,24 \%)$ a výtvarnou výchovu $(18,24 \%)^{8}$. Dále viz tabulka 1.

\begin{tabular}{|c|c|c|}
\hline Odpověd’ & Počet & $\%$ \\
\hline \multicolumn{3}{|l|}{ Věk } \\
\hline 12 & 186 & $30,85 \%$ \\
\hline 14 & 135 & $22,39 \%$ \\
\hline 13 & 119 & $19,73 \%$ \\
\hline 15 & 102 & $16,92 \%$ \\
\hline 16 & 34 & $5,64 \%$ \\
\hline 11 & 25 & $4,15 \%$ \\
\hline 10 & 2 & $0,33 \%$ \\
\hline \multicolumn{3}{|c|}{ Navštěvovaná třída } \\
\hline 6. třída & 229 & $37,98 \%$ \\
\hline 8. třída & 136 & $22,55 \%$ \\
\hline 9. třída & 128 & $21,23 \%$ \\
\hline 7. třída & 110 & $18,24 \%$ \\
\hline \multicolumn{3}{|l|}{ Oblíbený předmět } \\
\hline Tělocvik & 287 & $47,60 \%$ \\
\hline Informatika & 155 & $25,70 \%$ \\
\hline Matematika & 110 & $18,24 \%$ \\
\hline Výtvarná výchova & 110 & $18,24 \%$ \\
\hline Dějepis & 104 & $17,25 \%$ \\
\hline Cizí jazyk & 101 & $16,75 \%$ \\
\hline Přírodopis & 85 & $14,10 \%$ \\
\hline Hudební výchova & 82 & $13,60 \%$ \\
\hline Zeměpis & 68 & $11,28 \%$ \\
\hline Fyzika & 45 & $7,46 \%$ \\
\hline Český jazyk & 42 & $6,97 \%$ \\
\hline Chemie & 34 & $5,64 \%$ \\
\hline Občanská výchova & 31 & $5,14 \%$ \\
\hline Svět práce & 21 & $3,48 \%$ \\
\hline Další odpovědi (31) & 51 & $8,75 \%$ \\
\hline
\end{tabular}

Tab. č. 1: Shrnutí vybraných demografických údajů $(N=603)$.

\footnotetext{
${ }^{8}$ Toto zjištění koresponduje i s výzkumným šetřením Minisčítání, který v roce mezi dětmi provedl Český statistický úřad - viz Minisčítání - výsledky. (2015). Dostupné $\mathrm{z}$ https://vdb.czso.cz/pll/eweb/mini2015.vysledky?kr=x\&o=3\&m=1
} 


\section{Výsledky výzkumu}

Dotazníkové šetření rozdělilo respondenty do několika skupin: (1) ti, kteří digitální hry vůbec nehrají, (2) ti, kteří se s digitální hrou setkali ve výuce a (3) ti, již se s ní ve školním prostředí nesetkali. Jen malá část respondentů toto médium vůbec nereflektuje $(7,46 \%$; první skupina). Jak již bylo uvedeno výše, tento stav byl poměrně předpokládatelný a srovnatelný s vývojem v posledních letech, jak dokazují i výzkumné nebo konzumentské studie (např. Futurelab, 2006; ISFE, 2012; ESA, 2015; ESA, 2017). Druhá a třetí skupina byly zastoupením poměrně podobné $(51,25 \%$ se s digitální hrou ve výuce nesetkalo, $48,75 \%$ ano), což velice přesně koresponduje s předcházejícím výzkumem mezi učiteli (Picka, 2017), kde byli učitelé děleni dle toho, zda ve výuce používají digitální hry $(51,02 \%-\mathrm{Ne}, 48,98 \%$ - Ano). Další podskupinu respondentů tvořili ti, již se setkali se vzdělávací digitální hrou, tedy hrou prrímo určenou a designovanou pro vzdělávací účely $(75,8 \%) .16 \%$ se se vzdělávací digitální hrou nesetkalo nikdy a nikde, $76 \%$ z nich by si přitom ani nechtělo takovou hru vyzkoušet. Je těžké odhadovat, na jakém základě žáci odpovídali na tuto položku - at' již z obavy, že hry vytvářené pro vzdělávací účely budou nudné, nebo z nedostatečného zájmu o vzdělávání pomocí digitálních her.

Respondentů vnímajících přínos konkrétní hry čítalo 52,69 \% (žádný přínos nevnímalo $47,31 \%$ ). Většina však již pak uvedený titul hry dále nereflektovala (při zhodnocení zvolené konkrétní hry se respondenti často uchylovali k možnosti nevím - tuto odpověd' uvedlo u většiny otázek z této oblasti okolo $30 \%$ respondentů). Zřejmě to bylo způsobeno tím, že respondenti byli „zaskočeni“ položkami směřujícími ke konkrétnímu titulu, který měli sami napsat, resp. doposud o této hře z hlediska jejího přínosu pravděpodobně nepřemýšleli. I tak však baterie splnila svůj účel (tedy zjistila, že žáci identifikují zvolenou hru jako něco, co jim pomůže si látku lépe zapamatovat (57,9 \%), nebo že se hrou naučí více než bez ní - 56,5\%), nicméně je na škodu, že se tuto skutečnost nepodařilo lépe odhalit během pilotáže.

Co se týče frekvence hraní digitálních her (na PC a herních konzolích), největší část respondentů hraje každý den (33,69 \%) nebo alespoň třikrát (nebo vícekrát) do týdne $(25,27 \%)$. Pouze několikrát do měsíce hraje jen malá část dotázaných (11,6\%). Zjištění jsou poměrně předpokládatelná dle vývoje (viz studie víše - napřr. ISFE, 2012; ESA, 2015; ESA, 2017) a také vzhledem k tomu, že dnešní výkonné mobilní telefony umožňují hrát kdykoliv a kdekoliv, i když nevlastní dedikované herní zařízení. To ostatně souvisí s uváděnou frekvencí hraní na mobilním telefonu. Zde dokonce $42,5 \%$ respondentů udává, že na mobilním telefonu hraje každý den, respektive třikrát a vícekrát během jednoho týdne (22,9 \%). Několikrát do měsíce pak pouze $9,5 \%$ respondentů. Co se týče oblíbenosti žánrů, je opět poměrně předpokládatelná (ESA, 2015, 2017) velká obliba FPS her (akční hry z pohledu první osoby) - 44,6 \%. Zajímavé ovšem je, že hodně diskutované MMORPG ${ }^{9}$ hry nemají respondenti v nijak velké oblibě (jen 10,9\%), i navzdory tomu, že tento typ her je stále celosvětově velice populární (SuperData, 2016). Lze to vysvětlit především věkem respondentů a související jazykovou bariérou těchto her, protože většinou nejsou distribuovány $\mathrm{v}$ české lokalizaci a $\mathrm{z}$ důvodu střetávání se hráčů z celého světa je dobrá znalost angličtiny esenciální.

\footnotetext{
${ }^{9}$ MMORPG (Massive(ly)-Multiplayer Online Role-Playing Game) je počítačová hra na hrdiny o více hráčích, která umožňuje tisícům hráčů po celém světě být $v$ jeden čas na jednom místě, ve zpravidla fiktivním virtuálním světě skrze internet.
} 
Zajímavé jsou také výsledky týkající se vlastního subjektivního vnímání sebe jako hráče her. Pojem hráč je mezi dětmi poměrně dobře uchopitelný a v širším slova smyslu definuje osobu jako někoho, u koho je hraní digitálních her jedním z definujících koníčků; jedná se tedy i o věc určitého statusu nebo popisu osobnosti. Velká část respondentů se za hráče považovala (celkem $53 \%$ ).

Nejčastěji se respondenti setkávají se vzdělávacími digitálními hrami, dle očekávání, ve školním prostředí $(37,46 \%)$ a doma $(36,56 \%)$. Jen minimálně se s nimi setkávají v rámci kroužků $(0,9 \%)$, ačkoliv nabídka zájmových útvarů zaměřených na informatiku (předmět, $v$ němž se respondenti setkávají s hrami nejčastěji), popř́padě i na počítačové hry (hlavně jejich tvorbu) jako takové, dnes není malá, a to i prímo na školách. Př́istup rodičủ ke hrám jakožto možnému vzdělávacímu médiu začíná být poměrně více benevolentní a chápající, či dokonce podporující - $\mathrm{k}$ tomu ostatně docházejí i některé studie (např. Anderson, 2009; ISFE, 2012). Více než třetina (35,13 \%) respondentů se tak s digitální hrou pro podporu vzdělávání setkala díky svým rodičům. Na druhou stranu, žáci nemají velký zájem si hry pro vlastní učení dohledávat sami (26,9\%).

\subsection{Vztah k ICT}

S digitálními hrami je do jisté míry propojena i problematika ICT, nicméně uživatelské znalosti potřebné $\mathrm{v}$ dnešní době $\mathrm{k}$ běžné obsluze počítače jsou výrazně nižší. Přestože drtivá většina dotázaných $(92,5 \%)$ aktivně hraje hry, a to i s poměrně vysokou frekvencí (viz dále), jejich zájem o výpočetní techniku je řádově menší. Jen asi třetina dotázaných $(34,6 \%)$ se zajímá o novinky ve výpočetní technice. Podobně velká skupina respondentů (36 \%) si někdy zkoušela vytvořit vlastní webové stránky (tato oblast se objevuje v určité míre i na základních školách v hodinách informatiky) a $38 \%$ se pokoušelo zapojovat počítačové komponenty. Stojí za povšimnutí, že takřka polovina dotázaných $(49,25 \%)$ zkoušela někdy v minulosti programovat (at' již v klasických nebo cvičných jazycích). Vzhledem $\mathrm{k}$ podstatně menšímu zastoupení ostatních řešených dovedností by se $\mathrm{v}$ této věci nabízel další výzkum, at' již mezi žáky nebo mezi učiteli.

\subsection{Hry a škola}

Jak již bylo uvedeno výše, skupiny respondentů, kteří se s digitálními hrami ve škole setkali a kteří nikoli, byly početně poměrně vyvážené $(51,25 \%$ - Ne, 48,75 - Ano). Nejčastěji žáci uváděli, že se setkávali s tímto médiem v informatice $(60,14 \%)$, cizích jazycích $(22,7 \%)$, českém jazyce $(21,7 \%)$ a v matematice $(14 \%)$. V ostatních předmětech pak bylo toto médium zastoupeno méně než z $10 \%$ (dále tabulka 2 ). Je poměrně překvapivé, že jen velice málo žáků se setkalo s hrami v občanské výchově $(5,9 \%)$, vzhledem $\mathrm{k}$ tomu, že právě pro tento předmět vyšlo i několik ryze českých her, např́klad GhettOut - trenažer životnich strategii (2009)10 nebo Evropa 2045 (Brom, Šisler, \& Slavík, 2010). Může být i do jisté míry překvapivé, že se žáci setkali s hrami i v hodinách tělesné výchovy (5\%), nicméně i zde existuje řada pohybových titulů, jako napríklad Dance Dance Revolution. Za všechny předměty pak lze říci, že výuka připadá žákům zábavnější, pokud jsou během ní digitální hry použity $(80,51 \%)$.

\footnotetext{
${ }^{10}$ Online hratelná verze hry GhettOut (2009). Dostupné z http://www.ghettout.cz/.
} 


\begin{tabular}{|l|l|l|}
\hline Odpověd' & Počet & $\%$ \\
\hline \multicolumn{2}{|l|}{ Předmět, kde se žáci setkali s hrami. } \\
\hline Informatika & 172 & $60,14 \%$ \\
\hline Cizí jazyk & 65 & $22,73 \%$ \\
\hline Český jazyk & 62 & $21,68 \%$ \\
\hline Matematika & 40 & $13,99 \%$ \\
\hline Př́rodopis & 27 & $9,44 \%$ \\
\hline Dějepis & 21 & $7,34 \%$ \\
\hline Zeměpis & 21 & $7,34 \%$ \\
\hline Občanská výchova & 17 & $5,94 \%$ \\
\hline Tělocvik & 14 & $4,90 \%$ \\
\hline Hudební výchova & 14 & $4,90 \%$ \\
\hline Rodinná výchova & 11 & $3,85 \%$ \\
\hline Výtvarná výchova & 11 & $3,85 \%$ \\
\hline Fyzika & 10 & $3,50 \%$ \\
\hline Chemie & 7 & $2,45 \%$ \\
\hline Svět práce & 6 & $2,10 \%$ \\
\hline
\end{tabular}

Tab. č. 2: Předměty, v nichž se žáci s hrami setkali.

\subsection{Vnímání učení se s digitálními hrami}

Vnímání digitálních her v kontextu vzdělávání bylo u respondentů spíše pozitivní $(\mathrm{x}=$ $3,65 ; \mathrm{SD}=0,45)$. Jen $15 \%$ z nich se domnívalo, že hry jsou médium, které do škol nepatř́í, a $14,7 \%$ se z her ničemu novému nenaučí. Naopak $63,3 \%$ respondentů souhlasilo, že více přemýšlejí o tématech, $\mathrm{s}$ nimiž se $\mathrm{v}$ hrách setkávají, a 56,3\% se díky digitálním hrám zajímají i o témata, která je dříve nezajímala. Respondenti také vidí v hrách médium, jež by se mělo ve školách běžně používat $(63,04 \%)$. Ostatně by v tom nemusel být zásadní problém, a to vzhledem $\mathrm{k}$ tomu, že digitálním hrám coby výukové metodě se nebrání ani oslovení učitelé, kteří se domnívají, že hry jsou minimálně stejně vhodné jako jiné výukové metody (69 \%) a že jim pomáhají látku lépe vizualizovat (76,3\%) (Picka, 2017).

Pokud pohlédneme na vnímání učení se s digitálními hrami z hlediska různých skupin žáků (z hlediska hraní digitálních her, navštěvovaného ročníku, obecného vztahu k ICT), statisticky významný rozdíl lze pozorovat pouze mezi žáky s různým vztahem $\mathrm{k}$ ICT ( $\mathrm{X}^{2}$ $=18,59 ; \mathrm{p}<0,001)^{11}$. Nejpozitivněji vnímali digitální hry žáci s velmi silným vztahem $\mathrm{k}$ ICT $(\mathrm{x}=2,94 ; \mathrm{SD}=1,56)$. Statisticky významný rozdíl nebyl zjištěn jak mezi žáky, kteří s digitálními hrami ve výuce již zkušenost mají $(\mathrm{N}=272)$ a kteří nikoli $(\mathrm{N}=286 ; \mathrm{Z}=$ $0,79 ; p=0,43)$, tak mezi žáky z různých ročníků $\left(X^{2}=5,80 ; p=0,12\right)$.

\footnotetext{
${ }^{11}$ Konkrétně mezi žáky s velmi slabým vztahem k ICT a silným vztahem k ICT $(\mathrm{p}<0,001)$ a slabým vztahem k ICT a silným vztahem k ICT $(\mathrm{p}<0,05)$.
} 


\subsection{Motivace k hrani digitálnich her}

Jako poměrně silně motivující faktor se dle výpovědí respondentů jeví rozvoj jejich vlastní fantazie $(77,4 \%$ - souhlasím + spišse souhlasím). Toto zjišsění koresponduje i s názory rodičŭ, které byly zjištovány ve výzkumu ISFE (2012). Rodiče vnímali právě tuto vlastnost digitálních her jako kladnou a významnou. Stejně tak žáci souhlasili s výrokem, že je digitální hry udržují v aktivitě, resp. „ve střehu“ $(64,4 \%$ - souhlasím + spišse souhlasim). Převážná většina respondentů (63,8 \%) také inklinovala ke kompetitivní motivaci - úspěch ve hře v porovnání s ostatními se jeví jako silný motivační faktor (viz obr. č. 1).

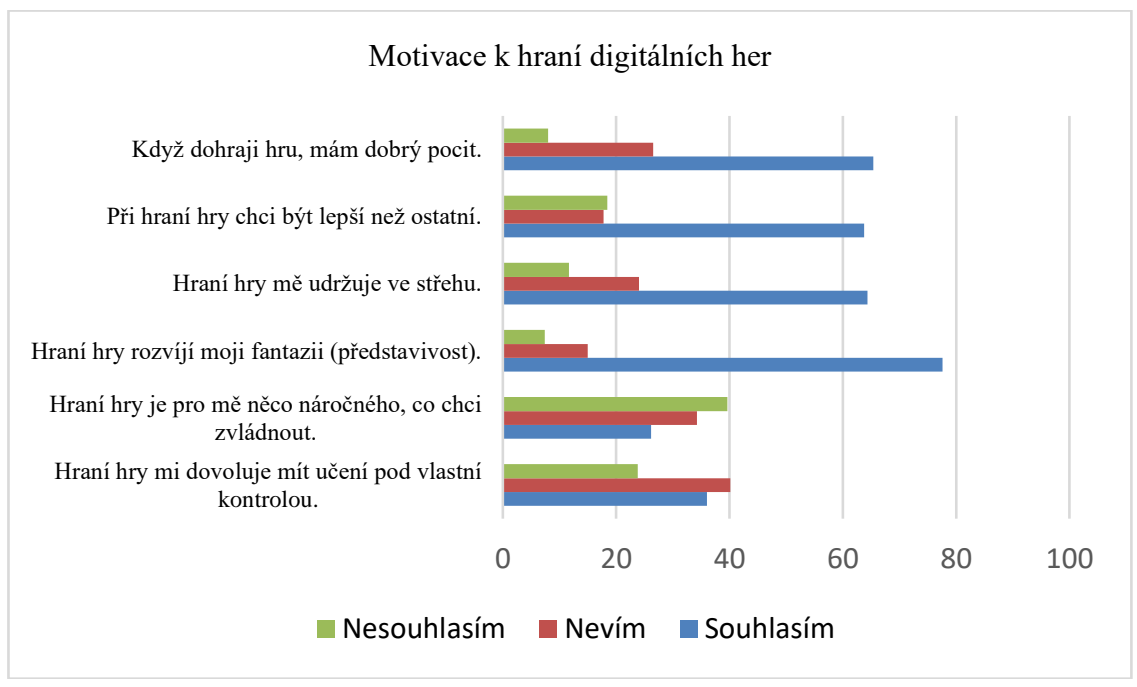

Obr. č. 1: Motivace k hrani digitálních her

K osobním motivačním faktorům (dle Malone a Lepper, 1987) patří i forma kontroly nad prostředím, kde je možné hru (učební prvek) úspěšně dokončit. $\mathrm{S}$ tímto motivačním faktorem se ztotožňuje $65,42 \%$ respondentů. Ostatně digitální hra většinou graduje, ke konci bývá těžší a hráče odmění at již formou narativu (pointou příběhu, kde hráč zaujímá pozici hlavního hrdiny), nebo odměny (nových mechanismů) pro další fázi hry, což je samožrejmě motivující, hlavně pokud je hra kvalitně vytvořená. Bohužel se zde často objevuje odpověd' nevím, jež ovlivňuje výsledné skóre oblasti $(\mathrm{x}=3,69 ; \mathrm{SD}=0,48)$, nicméně respondenti spiše inklinují k pozitivnímu vnímání. Jak je vidět i na přiloženém grafu (viz obr. č. 1), žáci dosahovali nejvyššího skóre v rámci motivace u rozvoje svojí fantazie $(\mathrm{x}=4,1 ; \mathrm{SD}=1,0)$, nejnižšího skóre pak při vnímání hry jako výzvy $(\mathrm{x}=2,78$; $\mathrm{SD}=1,25)$. 
Co se týče rozdílů mezi sledovanými skupinami žáků, byl podobně jako u vnímání učení se s digitálními hrami zjištěn statisticky významný rozdíl $\left(\mathrm{X}^{2}=70,41 ; \mathrm{p}<0,001\right)^{12}$. Největší motivaci měli žáci se silným vztahem k ICT $(x=3,33 ; \mathrm{SD}=1,53)$. Když porovnáme, jak v této oblasti odpovídali respondenti se zkušeností s digitálními hrami ve výuce $(\mathrm{N}=272)$ a bez ní $(\mathrm{N}=286)$, rozdíly v motivaci k učení se s digitálními hrami mezi skupinami žáků jsou taktéž statisticky významné $(Z=-2,17 ; p<0,05)$. Více motivovaní jsou ti, kteří zkušenost s digitálními hrami mají $(\mathrm{x}=3,67 ; \mathrm{SD}=1,22)$. Naproti tomu mezi žáky z různých ročníků nebyl zjištěn statisticky významný rozdíl $\left(\mathrm{X}^{2}=2,19 ; \mathrm{p}=0,53\right)$.

\subsection{Klady a zápory konkrétni vzdělávaci hry}

S digitální hrou, u níž měli respondenti pocit, že je něco nového naučila, se setkalo $52,69 \%$ respondentů. Ačkoliv identifikovali svoji vybranou hru jako médium, které jim umožnilo si látku lépe zapamatovat $(57,85 \%$ - souhlasím + spíše souhlasím) a rovněž je přivedlo k tématu, jež je předtím př́iliš nezajímalo (54\%), jen menší část $(40,5 \%)$ tento zážitek motivoval k tomu, aby si další informace k tématu, které hra obsahovala, dohledala (at' již v učebnici nebo na internetu). Respondenti rovněž považovali hru za médium, díky němuž se toho obecně naučí více, než by tomu bylo bez využití hry $(56,5 \%)$. Ostatně tato oblast je úzce propojena s motivací žáků - pokud hra funguje jako motivační element (viz předešlá oblast 5.4), dokážou u výuky strávit více času, než se unaví (viz např. Wang et al., 2010). Problémem celé oblasti bylo pak poměrně vysoké zastoupení odpovědi nevím napříč otázkami. Ačkoliv se tento problém neukázal v pilotním výzkumu, nemalá část respondentů, kteří na úvodní segmentační otázku odpověděli kladně, byla zjevně poněkud zaskočena následnými otázkami. Tomu odpovídá i celkový skór respondentů, jenž se pohybuje na hranici mezi 2 a $3(\mathrm{x}=2,51$; $\mathrm{SD}=0,44)$. Je tak sice vidět jistá inklinace směrem k negativnímu hodnocení, nicméně je u respondentů patrná určitá nejistota.

\section{Závěry a diskuse}

Naše studie poukázala na to, že žáci se při výuce s hrami setkávají v celé škále předmětů, především však v jazykovém vzdělávání a informatice, ale tento trend se nevyhýbá ani tělesné výchově. At' již jde o jakýkoliv předmět, žáci se shodují, že výuka je s tímto prvkem zábavnější. Setkání s tímto médiem však neprobíhá jen ve školní realitě, ale i v domácím učení, kde žákům vzdělávací hry často obstarává dnešní generace rodičů. Toto médium tedy dnešní žáky obklopuje, jsou zvyklí na jeho komunikační rámec, a tak je logické, že většina účastníků našeho dotazníkového šetření hry považuje za formu, jež by se ve školní výuce měla běžně používat a jeví se jako minimálně stejně vhodná jako jiné formy výuky. Vnímají hry jako něco, co jim pomáhá s vizualizací látky, pobízí je k dohledávání si dalších informací, rozvíjí jejich fantazii, nebo jsou motivující tím, že jim umožňují mít nad svým vlastním učebním procesem větší kontrolu. Ti žáci, kteří se ve výuce s hrami nesetkali, je však také vnímají většinou spíše pozitivně, dle některých položek spíše jako prvek, jejž by rádi ve výuce do budoucna viděli. Skutečnost, zda žák hrál digitální hru, nemá na vnímání učení se s digitální hrou vliv.

Toto zjištění je dobrým vodítkem pro budoucí výzkumy - je zhoršení vnímání digitálních her po jejich aplikaci do vzdělávání způsobeno nevhodným výběrem hry,

\footnotetext{
${ }^{12}$ Konkrétně mezi velmi silným a středně silným $(p<0,05)$, velmi silným a silným $(p<0,001)$, velmi silným a velmi slabým ( $\mathrm{p}<0,001)$, slabým a silným $(\mathrm{p}<0,001)$, slabým a velmi silným $(\mathrm{p}<0,001)$, středně silným a velmi silným vztahem k ICT $(\mathrm{p}<0,05)$.
} 
nevhodným zapojením, přehnaným očekáváním nebo zcela jiným faktorem? Toho se však nepodařilo tímto dotazníkovým šetřením dopátrat. Jako vhodnějši se $\mathrm{k}$ účelům zjištování konkrétních př́nosů digitálních her pro učení proto jeví kvalitativní metody sběru dat, např. rozhovory nebo focus groups s žáky.

Lze říci, že žáci obecně vnímají učení se s digitálními hrami neutrálně až pozitivně, a to napříč ročníky 2 . stupně ZŠ. Jak na vnímání, tak i na motivaci k hraní má vliv vztah žáka $\mathrm{k}$ ICT. Ti, kteří se obecně zajímají více o ICT, pravděpodobně o to více i hrají, což je pochopitelné vzhledem k úzkému vztahu digitálních her k počítači.

Největším problémem tak zůstává neochota žáků si tyto hry samostatně vyhledávat a dále pracovat $\mathrm{s}$ informacemi ze hry (jen $37 \%$ hra motivuje $\mathrm{k}$ dalšímu vyhledávání informací $\mathrm{k}$ tématu). Je však obtížné posoudit, zda je toto specifikum hry nebo jen obecná situace. S ohledem na jiné studie (např. Moravec \& Pešková, 2016) je také možné se domnívat, že „nová vzdělávací média“, včetně digitálních her, pravděpodobně žáci pozitivně přijímají z důvodu jejich „novosti“, atraktivnosti či nevšednosti. Také však proto, že se jedná o média, s nimiž se běžně setkávají i při trávení volného času. Jsou tedy na konzumaci této formy zvyklí a je to pro ně motivující.

Srovnání s obdobnými studiemi se stalo poněkud obtížnější, protože výzkumy z pohledu žáků na tuto problematiku prakticky neexistují, a to jak v kontextu českém, tak i zahraničním. Studie zabývající se motivací (např. Hainey et al., 2013) zase operují s diametrálně jinou věkovou kategorií, která přece jen vnímá hry již poněkud jinak a takové srovnání je jen málo vypovídající. Jedná se tedy o oblast, již je potřeba daleko více prozkoumat. Obecně lze však říci, že studie Haineyho a kol. (2013) koresponduje $\mathrm{s}$ výsledky naší studie jen zčásti. Zatímco participanti obou studií se shodují na tom, že hry v jejich učení jsou pozitivním faktorem a ve vyučovacím procesu je chtějí, u motivace se výsledky rozcházejí. Respondenti naší studie vnímají kupř́íkladu nejpozitivněji efekt posílení fantazie, zatímco respondenty Haineyho studie (2013) není tento motiv vysoce hodnocen. Naopak také vycházejí výsledky pro hru jako výzvu - pro naše respondenty není výrazný motiv, zatímco u Haineyho (2013) respondentů se jedná o prioritní motiv. Tyto protiklady lze však připsat právě diametrálně odlišenému věkovému složení participanti̊ a rovněž užšímu vzorku, který obsahoval pouze studenty vysoké školy.

Tato studie taktéž potvrzuje výsledky výzkumu mezi učiteli (Picka, 2017) v tom, že prakticky polovina žáků se setkává ve výuce s digitálními hrami. Jedná se tedy o vzdělávací médium, které je v naší pedagogické realitě používáno. Pochopení, co konkrétně žáky na hrách v učebním procesu motivuje, jak vnímají jednotlivé aspekty digitálních her a jaká jsou pozitiva a negativa jejich zapojení, je dalším zásadním bodem, jejž je třeba prozkoumat více do hloubky. Především $z$ toho důvodu, aby toto médium bylo využíváno efektivně a ve prospěch vzdělávacího procesu jako celku.

\section{Literatura}

Adams, P. (1998). Teaching and learning with SimCity 2000. Journal Of Geography, 97(2), 47-155.

Anderson, N. (2009). Equity and information communication technology (ICT) in education. New York: Peter Lang.

Bekebrede, G., Warmelink, H. J. G., \& Mayer, I. S. (2011). Reviewing the need for gaming in education to accommodate the net generation. Computers, 57(2), 1521-1529.

Bendermacher, N. (2010). Beyond alpha: Lower bounds for the reliability of tests. Journal of Modern Applied Statistical Methods, 9(1), 95-102. 
Bourgonjon, J., Valcke, M., Soetaert, R., \& Schellens, T. (2010). Students' perceptions about the use of video games in the classroom. Computers \& Education, 54(4), 114511156.

Breslin, G. (2012). Collins dictionary (11th ed.). Glasgow: HarperCollins.

Brom, C., Šisler, V., \& Slavík, R. (2010). Implementing digital game-based learning in schools: Augmented learning environment of 'Europe 2045'. Multimedia Systems, 16(1), 23-41.

Bruckman, A. (1999, březen). Can educational be fun? Př́spěvek prezentovaný na konferenci Game Developer's Conference, San Jose, California.

Clancy, M. (2004). Misconceptions and attitudes that interfere with learning to progam. In S. Fincher \& M. Petre (Eds.), Computer science education research. (s. 85-100). New York: Taylor \& Francis.

Cortina, J. M. (1993). What is coefficient alpha? An examination of theory and applications. Journal of Applied Psychology, 78(1), 98-104.

Cronbach, L. J. (1951). Coefficient Alpha and the internal structure of tests. Psychometrika, 16(3), 297-334.

Deci, E. L. (1971). Effects of externally mediated rewards on intrinsic motivation. Journal Of Personality And Social Psychology, 18(1), 105-115.

Denner, J., Werner, L., \& Ortiz, E. (2012). Computer games created by middle school girls: Can they be used to measure understanding of computer science concepts? Computers, 58(1), 240-249.

Deveau, J., Lovcik, G., \& Seitz, A. R. (2014). Broad-based visual benefits from training with an integrated perceptual-learning video game. Vision Research, 99, 134-140.

Entertainment software association (ESA). (2015). Essential facts about the computer and video game industry. ESA. Dostupné z http://www.theesa.com/wpcontent/uploads/2015/04/ESA-Essential-Facts-2015.pdf

Entertainment software association (ESA). (2017). Essential facts about the computer and video game industry. ESA. Dostupné $\mathrm{z}$ http://www.theesa.com/wpcontent/uploads/2017/09/EF2017_Design_FinalDigital.pdf

Futurelab. (2006). Teaching with games: COTS games in the classroom. Př́spěvek prezentovaný na online konferenci Transforming Learning Experiences.

Garris, R., Ahlers, R., \& Driskell, J. E. (2002). Games, motivation, and learning: A research and practice model.Simulation \& Gaming, 33(4), 441-467.

Ghettout. (2008). Ghettout. Dostupné z http://www.ghettout.cz/

Habgood, M. P. J., \& Ainsworth, S. E. (2011). Motivating children to learn effectively: Exploring the value of intrinsic integration in educational games. Journal Of The Learning Sciences, 20(2), 169-206.

Hainey, T., Westera, W., Connolly, T. M., Boyle, L., Baxter, G., Beeby, R. B., \& Soflano, M. (2013). Students' attitudes toward playing games and using games in education: Comparing Scotland and the Netherlands. Computers \& Education, 53(69), 474-484.

Hopkins, I., \& Roberts, D. (2015). 'Chocolate-covered broccoli'? Games and the teaching of Literature. Changing English, 22(2), 222-236.

Charsky, D. (2010). From edutainment to serious games: A change in the use of game characteristics. Games and Culture, 5(2), 177-198.

IBM. (1983). Adventures in Math. (software). 
Interactive software federation Europe (ISFE). (2012). Videogames in Europe: 2012 Consumer Study. Videogames in Europe: Consumer Study 2012. Dostupné $\mathrm{z}$ http://www.isfe.eu/videogames-europe-2012-consumer-study

Janatová, L. (2009). Souvislost mezi hraním počítačových her a agresivitou. Studia paedagogica, 14(2), 155-170.

Kruesmann, M (2014) Now showing: Using film as an educational medium in British schools. Policy \& Practice: A Development Education Review, 18, 15-29.

Malone, T. W., \& Lepper, M. R. (1987). Making learning fun: A taxonomy of intrinsic motivations for learning. In R. Snow, M. J. Farr (Eds.), Aptitude, learning and instruction Volume 3: Conative and affective process analysis (s. 223-253). Hillsdale, NJ: Lawrence Erlbaum.

Minisčítání 2015. (2015). Minisčitáni 2015. Dostupné z https://www.czso.cz/csu/miniscitani/miniscitani-2015.

Moravec, J., \& Pešková, K. (2016). Lower secondary school pupils' perception of etextbooks. E-Pedagogium, 3(11), 75-90.

Philpot, T., Hall, R., Hubing, N., \& Flori, R. (2005). Using games to teach statics calculation procedures: Application and assessment. Computer Applications in Engineering Education, 13(3), 222-232.

Picka, K. (2017). Digital games in education from the perspective of teachers. Journal of Technology and Information, 9(1), 156-174.

Proctor, M. D., \& Marks, Y. (2013). A survey of exemplar teachers' perceptions, use, and access of computer-based games and technology for classroom instruction: The origin, evolution, and impact of doi moi. Computers \& Education, 62(2), 171-180.

Radu, I. (2014). Augmented reality in education: A meta-review and cross-media analysis. Personal And Ubiquitous Computing, 18(6), 1533-1543.

Robertson, J., \& Howells, C. (2008). Computer game design: Opportunities for successful learning. Computers, 50(2), 559-578.

Robertson, J., \& Nicholson, K. (2007). Adventure author: A learning environment to support creative design. In Proceedings of the 6th international conference on Interaction design and children, IDC 2007, s. 37-44.Segers, E., \& Verhoeven, L. (2005). Long-term effects of computer training of phonological awareness in kindergarten. Journal of Computer Assisted Learning, 21(1), 17-27.

Shin, N., Sutherland, L. A. M., Norris, C. A., \& Soloway, E. (2012). Effects of game technology on elementary student learning in mathematics. British Journal Of Educational Technology, 43(4), 540-560.

Short, D. (2012). Teaching scientific concepts using a virtual world - Minecraft. Teaching Science, 58(3), 55-58.

Squire, K. D. (2008). Video game-based learning: An emerging paradigm for instruction. Perf. Improvement Quarterly, 21(2), 7-36.

SuperData. (2016). North America digital games market report 2016. New York: SuperData.

Takeuchi, L. M., \& Vaala, S. (2014). Level up learning: A national survey on teaching with digital games. New York: The Joan Ganz Cooney Center at Sesame Workshop.

Tannahill, N., Tissington, P., \& Senior, C. (2012). Video games and higher education: What can "call of duty" teach our students? Frontiers in Psychology, 3(210). Vos, N., van der Meijden, H., \& Denessen, E. (2011). Effects of constructing versus playing an 
educational game on student motivation and deep learning strategy use. Computers, 56(1), 127-137.

Wang, H.-S., Tsai, S.-N., Chou, C.-H., \& Hung, H.-J. (2010). The study of motivation and reasoning faculties of game-based learning in elementary school students. Př́spěvek prezentovaný na konferenci 2Nd International Conference On Education Technology And Computer, V3-247-V3-251. Dostupné z http://doi.org/10.1109/ICETC.2010.5529554 Watson, W., \& Yang, S. (2016). Games in schools: Teachers' perceptions of barriers to game-based learning. Journal Of Interactive Learning Research, 27(2), 153-170.

What is Alice. (2013).

$\mathrm{z}$ http://www.alice.org/index.php?page=what_is_alice/what_is_alice

Dostupné 